\title{
DETERMINATION OF ESSENTIAL OIL COMPOSITION, PHENOLIC CONTENT, AND ANTIOXIDANT, ANTIBACTERIAL AND ANTIFUNGAL ACTIVITIES OF MARIGOLD (CALENDULA OFFICINALIS L.) CULTIVATED IN ALGERIA
}

\author{
Imane Ourabia ${ }^{1}$, Réda Djebbar ${ }^{2}$, Samira Tata $^{3}$, Nasserdine Sabaou ${ }^{3}$, Djamila Fouial-Djebbar $^{\text {* }}$ \\ ${ }^{1}$ Laboratory of Functional Organic Analysis, Faculty of Chemistry, University of Sciences and Technology Houari \\ Boumediene (USTHB), EL Alia, BP 32, Bab Ezzouar, 16111 Algiers, Algeria \\ ${ }^{2}$ Laboratory of Biology and Physiology of Organisms, Faculty of Biological Sciences, University of Sciences and \\ Technology Houari Boumediene (USTHB), El Alia, BP 32, Bab Ezzouar, 16111 Algiers, Algeria \\ ${ }^{3}$ Laboratory of Biology of the Microbial Systems, Department of Biology, Ecole Normale Supérieure El Bachir El-Ibrahimi \\ (E.N.S), BP 92, Kouba-Algiers, Algeria \\ *djebbar_djamila@yahoo.fr
}

https://doi.org/10.34302/crpjfst/2019.11.2.8

\begin{tabular}{|c|c|}
\hline Article history: & ABSTRACT \\
\hline $\begin{array}{l}\text { Received: } \\
\text { 30 December } 2018 \\
\text { Accepted: } \\
\quad 10 \text { April } 2019\end{array}$ & $\begin{array}{l}\text { Microwave-assisted hydrodistillation (MAHD) was used as an ecofriendly } \\
\text { method to extract the essential oils from flowers and leaves of Calendula } \\
\text { officinalis L. cultivated in Algeria. The results obtained were compared } \\
\text { with the conventional extraction method, hydrodistillation (HD), and }\end{array}$ \\
\hline $\begin{array}{l}\text { Keywords: } \\
\text { Calendula officinalis L.; } \\
\text { Essential oil; } \\
\text { Phenolic compounds; } \\
\text { Antioxidant activity; } \\
\text { Biological activity. }\end{array}$ & $\begin{array}{l}\text { analyzed by gas chromatography-flame ionization detector (GC-FID) and } \\
\text { GC-MS. For flowers oils, } 33 \text { compounds were identified with HD method } \\
\text { vs } 20 \text { compounds with MAHD method. For leaves, } 26 \text { compounds were } \\
\text { identified with HD method vs } 19 \text { compounds identified with MAHD } \\
\text { method. It is interesting to note, furthermore, that the use of MAHD } \\
\text { method during } 90 \text { min allowed us to obtain relatively similar yields than } \\
\text { HD method during } 180 \text { min. The main abundant volatile constituent was } \alpha \text { - } \\
\text { cadinol with } 31.9 \pm 0.71 \% \text { for HD vs } 39.7 \pm 0.26 \% \text { for MAHD in leaves oils } \\
\text { and } 32.3 \pm 0.26 \% \text { for HD vs } 37.1 \pm 0.30 \% \text { for MAHD in flowers oils. The } \\
\text { oxygenated sesquiterpens was the most represented group of natural } \\
\text { compounds contributing to the chemical composition in all oils. In the } \\
\text { other hand, extraction of total phenolic compounds (TPC) and total } \\
\text { flavonoids (TFC) was affected by the solvent type and, thus, } 100 \% \\
\text { methanol was the better extraction solvent for both leaves and flowers. } \\
\text { Highest levels were obtained from leaves. The highest antioxidant activity } \\
\text { was recorded for leaves extract with } 100 \% \text { methanol. These values } \\
\text { indicated a weak antioxidant activity compared to antioxidant standards. A } \\
\text { correlation was established between the phenolic and flavonoids contents } \\
\text { and the antioxidant activity of the crude extracts. A moderate to great } \\
\text { antibacterial activity was observed against Gram bacteria. Any } \\
\text { antibacterial activity was detected against fungi strains and Gram bacteria. }\end{array}$ \\
\hline
\end{tabular}

\section{Introduction}

Pot marigold (Calendula officinalis L.) is an annual or biennial plant belonging to the Asteraceae family (Rotblatt 2000).
Native from Europe, Southern Africa, Western Asia and USA, Calendula officinalis L. is cultivated in temperate regions all over the world for their ornamental and medicinal 
purposes. The leaves are also used in paint coating, cosmetic and nylon industries (Muuse et al., 1992). In folk therapy, this species have been considered as values remedies against gastrointestinal ulcers, dysmenorrhea, fevers and conjunctivitis diseases (Lim 2014). It is mostly known for their high wound-healing properties (Nicolaus et al., 2017). In fact, it has been reported that the preparation of leaves applied in the form of compresses (Dei Cas et al., 2015), the oil and ointments from flowers (Jarić et al., 2018) and the tinctures or infusions made with aerial parts were employed to relieve,wounds , bruises, minor burns and skin damaged (Arora et al., 2013). Furthermore, many pharmacological investigations have demonstrated the biological effects of Calendula officinalis L. including antimicrobial (Gazim et al., 2008b) (Efstratiou et al., 2012) (Chebouti et al., 2014) (Shankar et al., 2017), anti-inflammatory (Ukiya et al., 2006, Amoian et al., 2010), hypoglycemic (Yoshikawa et al., 2001) antioxydant (Ćetković et al., 2004) ,anti-leishmanial (Nikmehr et al., 2014) and genotoxic effects (Bakkali et al., 2005).

Over the past decades, the essentials oils from medicinal plants have been isolated mainly by using hydrodistillation, steam distillation, maceration or expression (Ferhat et al., 2007). However, these conventional methods present some disadvantages such as the loss or the degradation of some thermolabile components due to the long extraction time and elevated temperatures (Luque de Castro et al., 1999). For these reasons, the various novel extraction techniques including hydrodiffusion, supercritical fluid extraction, ultrasound-assisted extraction and pressurized solvent extraction have been developed and investigated in order to decrease considerably the processing time, increase the extraction yield and enhance the quality of the extracts (Chan et al., 2011) (J. Mason et al., 2011). Among them, microwave assisted extraction in combination with hydrodistillation (MAHD) has been recognized as efficient alternative for isolation a complex mixture of bioactive compounds from plant sources (Farhat et al., 2017; Thach et al., 2013).

Concerning Calendula officinalis L., numerous authors have been reported that the chemical composition of essential oil have been conducted in which volatile constituents were extracted by hydrodistillation(HD) (Chalchat et al., 1991), headspace-solid phase microextraction (HS-SPME) (Gazim et al., 2008a), and supercritical $\mathrm{CO}_{2}$ (Crabas et al., 2003). However, according to our knowledge, no data are available about the essential oils from C. officinalis L. cultivated in Algeria.

Driven by this goal, we reported in this present study, for the first time, the chemical composition of the essential oil of leaves and flowers from Calendula officinalis L. extracted by microwave-assisted hydrodistillation. This extraction method was compared to hydrodistillation (as the reference method), in terms of extraction yields, extraction time and aromatic composition of the essential oils. On another hand, we focused our study to evaluate the influence of the extraction solvent type (methanol, ethanol absolute and ethyl acetate) on the phenolic and flavonoid contents and on the antioxidant and antimicrobial activities.

\section{Materials and methods \\ 2.1.Reagents}

6-hydroxy-2,5,7,8-tetramethylchromane-2carboxylic acid ( Trolox) ; 2,2-Diphenyl-1picrylhydrazyl (DPPH), acide 2'2, azino-bis(3-éthylebenzothiazoline)-6-sulfonique

$\left(\mathrm{ABTS}^{+}\right)$, Folin-Ciocalteu reagent, aluminium trichloride $\left(\mathrm{AlCl}_{3}\right)$, carbonate sodium $\left(\mathrm{Na}_{2} \mathrm{CO}_{3}\right)$, Butylhydroxytoluene (BHT), galic acid ,quercetine, persulfate $\left(\mathrm{K}_{2} \mathrm{~S}_{2} \mathrm{O}_{8}\right)$, extra pure sodium carbonate decahydrated $\left(\mathrm{Na}_{2} \mathrm{CO}_{3}\right)$ were purchased from Sigma-Aldrich (Steinheim, Germany). Mueller-Hinton (MH) and Sabouraud dextrose agar (SDA) were obtained from Merck (Darmstadt, Germany). 
All the solvents were of analytical grade. Alkane standards solutions $\left(\mathrm{C}_{7}-\mathrm{C}_{27}\right)$ were obtained from Fluka-chemika (Buchs, Switzerland).

\subsection{Vegetal material}

The aerials parts of Calendula officinalis $\mathrm{L}$. were cultivated and harvested from Birtouta area $\left(36^{\circ} 38^{\prime} 59^{\prime \prime}\right.$ North, $2^{\circ} 59^{\prime} 56^{\prime \prime}$ East) during mars 2017 at the flowering period. The authentication of the species was conducted in the department of Biology, University of Sciences and Technology Houari Boumediene, USTHB, Algiers.

\subsection{Hydro-distillation apparatus}

The vegetal material ( $400 \mathrm{~g}$ ) was subjected to hydrodistillation with Clevenger- apparatus during180 min. The essential oils extracted from flowers and leaves were collected and stored in amber vials at $4^{\circ} \mathrm{C}$ prior to analysis. The extraction time was selected following the previous

\subsection{Microwave-assisted hydrodistillation (MAHD) procedure}

MAHD was performed at atmospheric pressure using a household microwave oven (MW8123ST, Samsung, United Kingdom) connected with Clevenger-apparatus with a maximum delivered power of $1550 \mathrm{~W}$ in $100-\mathrm{W}$ increments. The vegetal material $(400 \mathrm{~g})$ was immerged in a $2 \mathrm{~L}$ flask containing distillate water $(1 \mathrm{~L})$ and heating using a fixed power of $588 \mathrm{~W}$ during $90 \mathrm{~min}$. The flask was introduced in the oven cavity of microwave, and the Clevenger apparatus was used on the top, outside the oven, to collect the volatile extracts which were stored at $4^{\circ} \mathrm{C}$ until being analyzed. The experiments were conducted in triplicate under the same conditions and the mean value was reported.

\subsection{General chromatographic conditions}

The constituents of the oils were analyzed using Hewlett-Packard 6890 series Gas
Chromatographic (GC) system (Agilent Technologies, Palo Alto, CA, USA) equipped with flame ionization detector (FID) set at $280^{\circ} \mathrm{C}$. The separation was achieved using HP5 MS apolar capillary column $(30 \mathrm{~m} \times 250 \mu \mathrm{m} \times$ $0.25 \mu \mathrm{m}$ film thickness). This column consists of $95 \%$ dimethylsilicone with $5 \%$ phenyl groups. The column temperature was initially programmed at $60^{\circ} \mathrm{C}$ for $8 \mathrm{~min}$ and increased to $250^{\circ} \mathrm{C}$ at $2^{\circ} \mathrm{C} / \mathrm{min}$, then finally held isothermally for $20 \mathrm{~min}$. The carrier gas was Helium at a flow rate of $0.5 \mathrm{~mL} \cdot \mathrm{min}^{-1}$ in split mode with an injection volume of $1 \mu \mathrm{L}$.

Gas chromatography-Mass spectrometry (GC-MS) analyses were performed using Hewlett-Packard 6890series GC system coupled with a mass spectrophotometer MSD 5973C and equipped with the same apolar capillary column .Temperature programming is the same as that used in the analysis by GCFID. Helium was carrier gas with a flow rate $1.5 \mathrm{~mL} / \mathrm{min}$. The injected volume was $0.2 \mu \mathrm{L}$ and the split ratio was 1:50. Injector temperature was $250^{\circ} \mathrm{C}$. The injected MS conditions were: MS source temperature: $230^{\circ}$ $\mathrm{C}$ and MS quadrapole temperature: $150^{\circ} \mathrm{C}$, the ionization mode used was electronic impact at $70 \mathrm{eV}$ over a scan range of $29-550$ atomic mass units.

In order to calculate the retention indices, the homologous $n$-alkanes $\mathrm{C}_{7}-\mathrm{C}_{27}$ was injected in the same conditions as the essential oils in GC-FID and GC-MS. The identification of volatile components was established by comparing their GC Kovats retention indices (KI) with those available in the literature and by matching their recorder mass spectral fragmentations patterns with those stored in the Wiley 9 and NIST 7N mass spectral library and others published index data (Adams 2007). Relative percentage amounts of each component are based on the peak areas obtained with GC-FID. 


\subsection{Analyzes of phenolic compounds}

\subsubsection{Extraction of phenolic compounds}

Powdered air-dried $(40 \mathrm{~g})$ flowers or leaves were macerated in solvents $(200 \mathrm{~mL})$ with different polarity: 100\% methanol, absolute ethanol and $100 \%$ ethyl acetate at room temperature for $24 \mathrm{~h}$. The suspension, thus obtained, was passed through the filter paper $\mathrm{N}^{\circ} 1$ (Whatman Ltd., UK) and concentrated under the vacuum on a rotary evaporator (Laborita 4001) at $40^{\circ} \mathrm{C}$. The final extracts were stored at $+4^{\circ} \mathrm{C}$ until utilization.

\subsubsection{Phenolic and flavonoid contents}

The total phenolic contents of the extracts were evaluated using the Folin-Ciocalteu method (Singleton et al., 1999). An aliquot $(250 \mu \mathrm{L})$ of the extracts, previously dissolved in the ethanol was added at Folin-Ciocalteu solution $(1250 \mu \mathrm{L})$. After 3 min of reaction, a solution of sodium carbonate $(1000 \mu \mathrm{l})$ at a concentration of 75 g. $\mathrm{L}^{-1}$ was added and the mixture was shaken a few seconds on the Vortex. The absorbance measurements were determined spectrophotometrically at $765 \mathrm{~nm}$. Gallic acid was used as a standard. Total phenolic content was expressed as milligrams gallic acid equivalent (GAE) per gram extract of dry mass (mg GAE. $\mathrm{g}^{-1} \mathrm{DM}$ ).

The trichloride aluminum method was used to quantify the total flavonoids contents of the samples(Menaceur et al., 2013) . To do this, an aliquot $(1000 \mu \mathrm{L})$ of the extract dissolved in the ethanol was mixed with of solution of trichloride aluminum $\mathrm{AlCl}_{3}(1000 \mu \mathrm{L}, 2 \%$ w/v).The absorbance was measured at $420 \mathrm{~nm}$ after $1 \mathrm{~h}$ of incubation at room temperature. The quercetin was considered as standard for the calibration curve. The flavonoids contents were expressed as milligrams of quercetin equivalent $(\mathrm{QE})$ per gram extract of dry mass (mg QE. $\left.\mathrm{g}^{-1} \mathrm{DM}\right)$. The experiments were carried out in triplicate.
2.7.Antioxidant activity

2.7.1.Diphenyl-2-picrylhydrazyl radical-scavenging effect

The DDPH free radical scavenging assay was used to evaluate the antioxidant activity of the obtained extracts according to the method previously described with minor modifications (Brand-Williams et al., 1995). Briefly, an ethanolic solution $(25 \mu \mathrm{L})$ of each sample at different concentrations (100-200-400-600-800 and1000 $\mu \mathrm{g} . \mathrm{mL}^{-1}$ ) were added to $975 \mu \mathrm{L}$ of DPPH-ethanol solution $(60 \mu \mathrm{M})$. After $30 \mathrm{~min}$ of incubation in the dark at room temperature, the absorbance was recorded at a wave length of $517 \mathrm{~nm}$ by using a spectrophotometer OPTIZEN 3220 UV. Butyl hydroxytoluene (BHT) was used as a standard antioxidant.

\subsubsection{ABTS free radical scavenging activity}

The ABTS test was assessed using the method reported by Ling et al (Ling et al., 2009). The ABTS radical cation was produced by reacting $7 \mathrm{mM}$ ABTS stock solution and $2.45 \mathrm{mM} \mathrm{K} \mathrm{S}_{2} \mathrm{O}_{8}$. The obtained mixture was kept in the dark at room temperature during 12$16 \mathrm{~h}$ prior use. The ABTS solution was diluted with ethanol in order to have a maximum absorbance of $0.703 \pm 0.025$ at $734 \mathrm{~nm}$. An aliquot of $20 \mu \mathrm{L}$ of the samples at various concentrations was added at $980 \mu \mathrm{L}$ of diluted ABTS solution. The decrease of absorbance measurement was monitored at $734 \mathrm{~nm}$ in the 6th min after adding the sample to the ABTS solution. The synthetic vitamin E (Trolox) was used as an antioxidant standard.

For both tests, the radical scavenging activity was calculated according to the following equation: $\%$ of radical scavenging activity $=[($ Abs control - Abssample $) / A b s$ control $] \times$ 100 , where Abscontrol is the absorption values of the blank sample and Abssample is the absorbance of the tested sample. The results were expressed as $\mathrm{IC}_{50}$ corresponding to the efficient concentration of the sample required to inhibit $50 \%$ of the free radical. The 
experiments were carried out in triplicate and the $\mathrm{IC}_{50}$ values were reported as means $\pm \mathrm{SD}$.

\subsection{Determination of antimicrobial activity}

The antibacterial activity of the crude extracts was evaluated following the paper disk diffusion method described by Bauer et al (Bauer et al., 1966) with slight modifications. For the experiments, the samples were tested against three $\mathrm{Gram}^{+}$bacteria: Bacillus subtilis ATCC6633, Listeria monocytogenese, Staphylococcus aureus MRSA 639c and two Gram- bacteria: Escherichia coli ATCC43300 and Pseudomonas aeruginosa ATCC 9027. Two pathogenic fungal strains: Aspergillus carbonarius M333 and Umbulopsis ramanniana NRRL1829 were also investigated. The bacterial and fungal strains were cultured in Mueller-Hinton (MH) at $37^{\circ} \mathrm{C}$ and Sabouraud dextrose agar (SDA) at $30^{\circ} \mathrm{C}$ respectively. Amoxicillin ( $25 \mu \mathrm{g} /$ disc) was used as the positive control while a disc impregnated with $25 \mu \mathrm{L}$ of DMSO was considered as the negative control. The appropriate agar mediums (MH or SDA) poured into Petri dishes were seeded with the cultures of microbial inoculum $\left(10^{6} \mathrm{CFU} / \mathrm{mL}\right)$ using a sterile cotton swab. Afterwards, the DMSOextract solutions $(25 \mu \mathrm{L})$ were added on the filter discs which were placed in the surface of Petri dishes. After staying at $4^{\circ} \mathrm{C}$ in the refrigerator during $1 \mathrm{~h}$ for diffusion, the Petri dishes were incubated during $24 \mathrm{~h}$ for the bacteria strains and $48 \mathrm{~h}$ for the fungi strains. Antibacterial activity was evaluated by measuring the diameter of the inhibition zones.

The extracts that showed antibacterial activity were screened for determination of minimum inhibitory concentration (MIC) by broth microdilution following National Committee for Clinical Laboratory Standards Guidelines with some modifications(Wikler 2009). A serial dilutions ranging between 7.8 to $500 \mu \mathrm{g} \cdot \mathrm{mL}^{-1}$ were carried out from an initial solution previously prepared in DMSO with concentration of $1000 \mu \mathrm{g} \cdot \mathrm{mL}^{-1}$. Then each solution $(0.5 \mathrm{~mL})$ was added to agar medium $(5 \mathrm{~mL})(\mathrm{MH}$ or SDA). After that, the obtained mixture was poured into the Petri dishes which were inoculated with inocula strains of $10^{6}$ CFU.mL ${ }^{-1}$ and incubated immediately at $37^{\circ} \mathrm{C}$ during $24 \mathrm{H}$ for the bacteria strains and $48 \mathrm{H}$ for fungi strains. Amoxicillin and DMSO served as a positive and negative control respectively. The minimum inhibitory concentration (MIC) is defined as the lowest concentration which exhibited no growth. The assays were carried out in triplicate.

\subsection{Statistical analysis}

The experiments were done in triplicate. The data were subjected to statistical analysis using one-way analysis of variance (ANOVA) with XLSTAT software on Microsoft Excel 2007. The results were expressed as mean \pm standard deviation (SD). The Student's t-test at $\mathrm{p}<0.05$ were considered statistically significant. Correlation was calculated according Pearson's method.

\section{Results and discussions}

\subsection{Quantitative and qualitative analyzes of essential oils} flowers.

Essential oils were studied in leaves and

\subsubsection{Effect of the extraction methods on the essential oils yields}

The overall yields were $0.045 \pm 0.004 \%$ (w/w) for HD vs $0.044 \pm 0.002 \%$ (w/w) for MAHD and $0.025 \pm 0.003 \%(\mathrm{w} / \mathrm{w})$ for HD $v s$ $0.023 \pm 0.003 \% \quad(\mathrm{w} / \mathrm{w})$ for MAHD for the essential oils extracting from flowers and leaves respectively (Figure 1). The oils yields obtained in $90 \mathrm{~min}$ ) using MAHD was relatively similar to that obtained after $180 \mathrm{~min}$ for HD method. Moreover, the extraction time required to reach an extraction temperature of $100^{\circ} \mathrm{C}$ to get the first essential oil droplet in only $5 \mathrm{~min}$ compared to $30 \mathrm{~min}$ for HD. It should be noted, furthermore, that the obtained 
yields are lower than those reported in the survey literature $(0.1-0.97 \%)$ (Chalchat et al., 1991) (Gazim et al., 2008a) (Khalid and ElGhorab 2006).

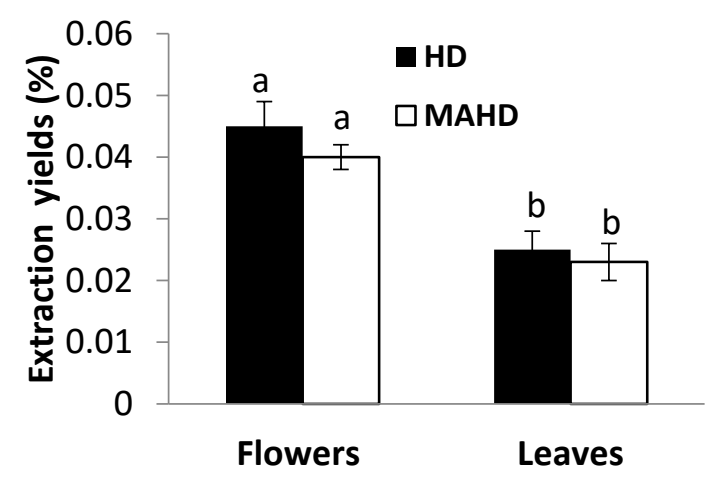

Figure 1. Extraction yields of essential oils from Calendula officinalis $L$. flowers and leaves with respect to extraction method.

Different alphabetical letters indicate statistically significant differences between values ( $\mathrm{p}<0.05$, Student's t-test). All values are mean $\pm \mathrm{SD}$. Error bars indicate standard deviation (SD).

\subsubsection{Effect of the extraction methods on the chemical composition of the essential oils}

The identified compound, their relative percentage, the experiments and literature retention indices are compiled in Table 1 and Table 2 for flowers and leaves essential oils respectively using HD and MAHD methods.

The analysis of the essential oils from flowers by GC and GC-MS allowed us to identify 33 compounds and 20 compounds representing $79.3 \%$ and $78.4 \%$ of the volatile oils constituents extracted by HD and MAHD respectively. The oils extracted were characterized in both methods by the predominance of two chemical families namely oxygenated sesquiterpens and sesquiterpens hydrocarbons. These compounds are responsible for the main biological activities of the vegetal matrice and their amounts depend closely to the used extraction method
(Amorati et al., 2013). The oil obtained by HD was little more concentrated in sesquiterpens hydrocarbons compounds compared with MAHD (22.6\% HD vs $21.1 \%$ for MAHD). Oppositly , the oxygenated sesquiterpens compounds were more abundant in the oil extracted by MAHD (57.2\%) than HD $(53.7 \%)$. It was observed, in addition, that the monoterpens hydrocarbons compounds (such as $\alpha$-pinene, $\alpha$-phellandrene and $\alpha$-terpinene) which represent $2.8 \%$ of the oils and the oxygenated monoterpens compounds $(0.2 \%)$ such as $(\alpha-\mathrm{E})$-ionone present with a relatively low percentage with HD method were absent or detected only at traces level using MAHD. The main abundant compounds were $\alpha$-cadinol (37.1 $\pm 0.26 \%$ for HD vs $32.3 \pm 0.3 \%$ for MAHD) followed by epi- $\alpha$-cadinol $(16 \pm 0.26 \%$ for HD vs $0 \%$ for MAHD), epi- $\alpha$ - Muurolol $(0 \%$ for HD vs $15.1 \pm 0.45 \%$ for MAHD),$\delta$-cadinene ( $13.1 \pm 0.52 \%$ for $\mathrm{HD}$ and $13.1 \pm 0.51 \%$ for MAHD), Torreyol $(2.7 \pm 0.36 \%$ for HD $v s$ $0.2 \pm 0.01 \%$ for MAHD) and Germacrene D ( $1.4 \pm 0.10 \%$ for HD vs $1.9 \pm 0.10 \%$ for MAHD).

Concerning the essential oils from leaves, 26 compounds were identified representing $80.1 \%$ of the oil extracted using HD while 19 compounds representing $88 \%$ were identified in oil extracted using MAHD. The major compounds identified and their respective percentage composition using both methods as follow as: $\alpha$-cadinol $(31.9 \pm 0.7 \%$ for $\mathrm{HD} v s$ $39.7 \pm 0.26 \%$ for MAHD), epi- $\alpha$-cadinol $(16.3 \pm 0.43 \%$ for HD vs $15.3 \pm 0.44 \%$ for MAHD), $\delta$-cadinene $(8.9 \pm 0.27 \%$ for HD $v s$ $18 \pm 0.44 \%$ for MAHD), Torreyol (3.2 $\pm 0.35 \%$ for HD vs $2.1 \pm 0.10 \%$ for MAHD) and $\alpha$ Humulene (1.9 $\pm 0.66 \%$ for HD vs $1.1 \pm 0.10 \%$ for MAHD). The established comparison between the chemical composition of the essential oils extracted by HD and MAHD methods showed a better abundance of oxygenated monoterpénes. 
Table 1. Chemical composition of essential oils extracted by hydrodistillation (HD) and microwaveassisted hydrodistillation (MAHD) from flowers of Calendula officinalis $L$.

\begin{tabular}{|c|c|c|c|c|c|}
\hline No & Compounds & $\mathbf{K I}^{(\mathbf{a})}$ & $\mathbf{K I}^{(\mathbf{b})}$ & HD $(\%)^{(\mathrm{c})}$ & MAHD (\%) \\
\hline 1 & $\alpha$-Pinene & 941 & 939 & $2 \pm 0.11$ & $\operatorname{Tr}$ \\
\hline 2 & $\alpha$-Phellandrene & 1005 & 1002 & $0,1 \pm 0.01$ & - \\
\hline 3 & $\delta$-3-Carene & 1013 & 1011 & $0,1 \pm 0.02$ & - \\
\hline 4 & $\alpha$-Terpinene & 1018 & 1017 & $0,1 \pm 0.01$ & $\operatorname{Tr}$ \\
\hline 5 & $p$-Cymene & 1024 & 1024 & $0,1 \pm 0.01$ & - \\
\hline 6 & $(Z-\beta)$ Ocimene & 1040 & 1037 & $0,1 \pm 0.01$ & $\mathrm{Tr}$ \\
\hline 7 & $y$-terpinène & 1062 & 1059 & $0,3 \pm 0.03$ & - \\
\hline 8 & Cis Sabinene hydrate & 1067 & 1070 & $\operatorname{Tr}$ & - \\
\hline 9 & $\beta$-bourbonene & 1386 & 1388 & $0,1 \pm 0.02$ & $0,1 \pm 0.01$ \\
\hline 10 & $\beta$-Cubebene & 1390 & 1388 & $0,1 \pm 0.01$ & - \\
\hline 11 & $\alpha$-gurgunene & 1399 & 1409 & $0,3 \pm 0.02$ & $0,4 \pm 0.03$ \\
\hline 12 & E-Caryophyllene & 1411 & 1419 & $1,1 \pm 0.10$ & - \\
\hline 13 & $(E-\alpha)$ Ionone & 1423 & 1430 & $0,2 \pm 0.01$ & - \\
\hline 14 & $\beta$-copaene & 1429 & 1432 & - & $0,1 \pm 0.03$ \\
\hline 15 & Cis Cadina-1(6),4-diene & 1464 & 1463 & $0,1 \pm 0.02$ & - \\
\hline 16 & Trans Cadina-1(6),4-diene & 1470 & 1476 & $0,2 \pm 0.01$ & $0,2 \pm 0.05$ \\
\hline 17 & $y$-Muurolene & 1481 & 1469 & $0,8 \pm 0.02$ & - \\
\hline 18 & Germacrene D & 1484 & 1485 & $1,4 \pm 0.10$ & $1,9 \pm 0.10$ \\
\hline 19 & $\beta$-Selinene & 1489 & 1490 & $0,2 \pm 0.02$ & - \\
\hline 20 & Trans. Muurola-4(4),5- diene & 1493 & 1493 & $0,2 \pm 0.03$ & $0,3 \pm 0.03$ \\
\hline 21 & $\alpha$-Muurolene & 1499 & 1500 & $2 \pm 0.50$ & - \\
\hline 22 & cubebol epi & 1502 & 1494 & - & $2,7 \pm 0.26$ \\
\hline 23 & $y$-Cadinene & 1506 & 1513 & $2 \pm 0.15$ & $4 \pm 0.20$ \\
\hline 24 & $\delta$-Cadinene & 1513 & 1518 & $13,1 \pm 0.52$ & $13,1 \pm 0.51$ \\
\hline 25 & $\alpha$-Cadinene & 1527 & 1530 & $0,5 \pm 0.02$ & $0,8 \pm 0.02$ \\
\hline 26 & $\alpha$-calacorene & $1545^{\text {(d) }}$ & 1545 & $0,5 \pm 0.03$ & $0,1 \pm 0.01$ \\
\hline 27 & Murool-5-en-4- $\beta$-ol-cis & 1552 & 1551 & - & $0,3 \pm 0.02$ \\
\hline 28 & Murool- 5-en-4- $\alpha$-ol-cis & 1559 & 1561 & - & $0,5 \pm 0.07$ \\
\hline 29 & Nerolidol & $1560^{(\mathrm{e})}$ & 1563 & $0,3 \pm 0.03$ & - \\
\hline 30 & $\beta$-calacorne & 1563 & 1565 & - & $0.1 \pm 0.01$ \\
\hline 31 & Palustrol & 1568 & 1568 & $0,3 \pm 0.01$ & $0,3 \pm 0.03$ \\
\hline 32 & caryophyllene oxide & 1586 & 1583 & - & $\operatorname{Tr}$ \\
\hline 33 & Cubeban-11-ol & 1596 & 1595 & $0,5 \pm 0.02$ & - \\
\hline 34 & Guiol & 1605 & 1600 & $0,2 \pm 0.02$ & - \\
\hline 35 & $\beta$-Oplopenone & 1609 & 1607 & $0,1 \pm 0.02$ & - \\
\hline 36 & Cubenol (1,10-di-epi-) & 1616 & 1619 & $0,4 \pm 0.05$ & $0.8 \pm 0.02$ \\
\hline 37 & Cubenol 1-epi- & 1629 & 1628 & $0,9 \pm 0.05$ & - \\
\hline 38 & epi $\alpha$-Cadinol & 1636 & 1640 & $16 \pm 0.26$ & - \\
\hline 39 & epi- $\alpha$-Muurolol & 1644 & 1642 & - & $15,1 \pm 0.45$ \\
\hline 40 & $\alpha$-Muurolol (=Torreyol) & 1646 & 1646 & $2,7 \pm 0.36$ & $0,3 \pm 0.01$ \\
\hline 41 & $\alpha$-Cadinol & 1655 & 1645 & $32,3 \pm 0.26$ & $37.1 \pm 0.30$ \\
\hline \multirow[t]{8}{*}{42} & Trans- calamenen-10-ol & 1672 & 1669 & - & $0,20 \pm 0.01$ \\
\hline & Extraction time & & & 180 & 90 \\
\hline & Yields & & & $0.045 \pm 0.02$ & $0.044 \pm 0.04$ \\
\hline & Monoterpens hydrocarbons(\%) & & & 2.8 & 0 \\
\hline & Oxyenated monoterps $(\%)$ & & & 0.2 & 0 \\
\hline & Oxygenated sesquiterpens (\%) & & & 53.7 & 57.3 \\
\hline & Sesquiterpens hydrocarbons (\%) & & & 22.6 & 21.1 \\
\hline & Total volatile compounds (\%) & & & 79.3 & 78.4 \\
\hline
\end{tabular}

Note: ${ }^{(a)}$ Experimental retention index relative to $\mathrm{C}_{7}-\mathrm{C}_{27} n$-alkanes on the HP5-MS (apolar capillary column), ${ }^{\text {(b) }}$ literature retention index. ${ }^{(c)}$ Percentage calculated by GC-FID on non-polar HP5-MS capillary column, ${ }^{\text {(d) }}$ Gazim et al. (2008a ), ${ }^{(e)}$ Okoh et al. (2008), tr: traces $(<0.1 \%)$, - : absence of compound. 
Compounds using HD (0.1\%) than MAHD $(0 \%)$ while a higher amounts of sesquiterpens hydrocarbons compounds were present in the essential oil extracted using MAHD compared to $\mathrm{HD}$ with a percentage of $27.4 \%$ and $24.6 \%$ respectively. Indeed, many volatile compounds including $\alpha$-cadinene $(0.9 \pm 0.01 \%$ for HD vs $1.3 \pm 0.25 \%$ for MAHD) and $\alpha$ muurolene $(3.4 \pm 0.40 \%$ for MAHD and $2.7 \pm 0.40 \%$ for $\mathrm{HD}$ ) were present in low amounts with HD method or were absent such as trans cadina-1,4-diene ( $1 \pm 0.41 \%$ for MAHD $v s \quad 0 \%$ for HD) and $\beta$-copaene (0.2 $\pm 0.02 \%$ for MAHD vs $0 \%$ for HD).

As the flowers oils, a greater proportion of the oxygenated sesquiterpens was observed in the leaves oil extracted by MAHD compared to HD (55.4\% HD vs $60.6 \%$ for MAHD). This difference in the essential oil composition is probably due to the high absorption of microwave by these polar compounds in MAHD more than in HD extraction which favorise a more easily extraction of these compounds compared with others class of compounds such as monoterpens hydrocarbons that have lower dipolar moments (Ferhat et al., 2006).

Furthermore, it is interesting to note that the quantities of the target compounds depend of the used extraction methods. According to the data values seen in the Table 2, the oxygenated sesquiterpens compounds of essential oil from leaves such as cubeban-11-ol and cubenol (1,10-di-epi) extracted by MAHD were present with a percentage of $1.2 \pm 0.66 \%$ and $0.6 \pm 0.020 \%$ respectively, or in the case of $\mathrm{HD}$, these volatile compounds were present at $0.9 \pm 0.040 \%$ and $0.5 \pm 0.010 \%$ respectively. Considering another compounds such as Torreyol and $\beta$-oplopenone, the essential oil obtained by HD showed the presence of these compounds with a percentage of $3.2 \pm 0.35 \%$ and $0.1 \pm 0.01 \%$ respectively against $2.1 \pm 0.10 \%$ and $0 \%$ respectively in the MAHD extract. In the same way, the study of the chemical composition of essential oils from flowers (Table 1) reveals the presence of epi $\alpha$-cadinol at $16 \pm 0.26 \%$ and 1 -epi cubenol at $0.9 \pm 0.05 \%$ using MAHD whereas these volatile compounds were absent in the oil obtained by HD. Otherwise, $\alpha$-muurolene and Ecaryophyllene present at $2 \pm 0.50 \%$ and $1.1 \pm 0.10 \%$ respectively in the HD extracts were absent in the oils extracted by MAHD.

In addition, in both oils, some volatile constituents such as caryophyllene oxide and $\alpha$ cubebene not detected using conventional extraction process were detected only at trace level by MAHD methods.

Regarding the aforementioned data, our finding was in agreement with those available in the literature. Indeed, the main component identified in this investigation in all oils $(\alpha$ cadinol) was similar to that reported by Chalchat et al (Chalchat et al., 1991) who studied C.officinalis L. from the French Central Massif. It has been reported also that the main components of essential oil from the Egyptian Pot Marigold cultivated under presowing low temperature were $\alpha$-cadinol (up to $64.4 \%$ ) following by $\Delta$-cadinene, $\delta$-cadenene and nerolidol (Khalid and El-Ghorab, 2006).

However, although the volatile compounds identified in this study were also mentioned by numerous authors, significant qualitative and quantitative differences were noted. This variation is probably due of the process factors, environmental conditions and/or genetic factors that affect the yield and quality of the essential oils (Duarte et al., 2017). The essential oils from Brazilian Pot Marigold were dominated by sesquiterpens hydrocarbons ( $68.0 \%$ of total area) and sesquiterpenols (27.0\% of total area) in which $\delta$-cadinene $(22.5 \%)$ and $\alpha$-cadinol (20.4\%) were the major constituents (Gazim et al., 2008a). Flowers oils from Bucharest (Romania) obtained by steam distillation was 
Table 2. Chemical composition of essential oils extracted by hydrodistillation (HD) and microwaveassisted hydrodistillation (MAHD) from leaves of Calendula officinalis L.

\begin{tabular}{|c|c|c|c|c|c|}
\hline No & Compounds & $\mathbf{K I}^{(\mathbf{a})}$ & $\mathbf{K \mathbf { I } ^ { ( \mathbf { b } ) }}$ & HD $(\%)^{(\mathrm{c})}$ & MAHD (\%) \\
\hline 1 & Bornyl acetate & $1285^{(\mathrm{d})}$ & 1288 & $0,1 \pm 0.01$ & - \\
\hline 2 & $\alpha$-cubebene & 1388 & 1386 & - & $\mathrm{Tr}$ \\
\hline 3 & $\beta$-bourbounene & 1390 & 1388 & $0,1 \pm 0.02$ & - \\
\hline 4 & $\alpha$-gurjunene & 1408 & 1409 & $0,3 \pm 0.02$ & $0,2 \pm 0.03$ \\
\hline 5 & caryophyllene E & 1418 & 1419 & $1 \pm 0.17$ & $0,4 \pm 0.040$ \\
\hline 6 & $\beta$-copaene & 1430 & 1432 & - & $0,2 \pm 0.02$ \\
\hline 7 & $\beta$-gurjunene & 1434 & 1433 & $0,1 \pm 0.01$ & $0,2 \pm 0.04$ \\
\hline 8 & $\alpha$-humulene & 1452 & 1454 & $1,9 \pm 0.66$ & $1,1 \pm 0.10$ \\
\hline 9 & Cis cadina-1-(6),4-diene & 1463 & 1469 & - & $0,4 \pm 0.02$ \\
\hline 10 & $\gamma$-muurolene & 1473 & 1479 & $1.8 \pm 0.20$ & $\operatorname{Tr}$ \\
\hline 11 & Trans.cadina-1-(6),4-diene & 1476 & 1471 & - & $1 \pm 0.49$ \\
\hline 12 & $\beta$-selinene & 1487 & 1490 & $0.4 \pm 0.01$ & - \\
\hline 13 & $\alpha$-muurolene & 1500 & 1500 & $2,7 \pm 0.40$ & $3,4 \pm 0.40$ \\
\hline 14 & $\gamma$-cadinene & 1513 & 1513 & $4,5 \pm 0.26$ & - \\
\hline 15 & $\delta$-cadinene & 1523 & 1523 & $8,9 \pm 0.27$ & $18 \pm 0.44$ \\
\hline 16 & Trans cadina-1,4-diene & 1534 & 1530 & - & $1 \pm 0.40$ \\
\hline 17 & $\alpha$-cadinene & 1537 & 1538 & $0,9 \pm 0.01$ & $1,3 \pm 0.25$ \\
\hline 18 & $\alpha$-calacorene & 1543 & 1538 & $0,6 \pm 0.05$ & - \\
\hline 19 & muurol-5-en-4- $\beta$-ol cis & 1550 & 1551 & $0,3 \pm 0.02$ & - \\
\hline 20 & muurol-5-en-4- $\alpha$-ol cis & 1561 & 1561 & $0,4 \pm 0.04$ & - \\
\hline 21 & $\beta$-calacorene & 1566 & 1565 & $0,6 \pm 0.02$ & - \\
\hline 22 & Palustrol & 1567 & 1568 & $0,3 \pm 0.02$ & - \\
\hline 23 & cubeban-11-ol & 1594 & 1595 & $0,9 \pm 0.40$ & $1,2 \pm 0.66$ \\
\hline 24 & $\beta$-oplopenone & 1609 & 1607 & - & $0,5 \pm 0.01$ \\
\hline 25 & cubenol(1,10-di-epi) & 1616 & 1619 & $0,5 \pm 0.010$ & $0,6 \pm 0.020$ \\
\hline 26 & $\alpha$-corocalene & 1623 & 1623 & $0,6 \pm 0.10$ & - \\
\hline 27 & cubenol 1-epi & 1629 & 1628 & $1,2 \pm 0.10$ & $1,2 \pm 0.20$ \\
\hline 28 & epi $\alpha$-cadinol & 1641 & 1644 & $16,3 \pm 0.43$ & $15,3 \pm 0.44$ \\
\hline 29 & Torreyol & 1646 & 1642 & $3,2 \pm 0.35$ & $2,1 \pm 0.10$ \\
\hline 30 & $\alpha$-cadinol & 1648 & 1654 & $31,9 \pm 0.26$ & $39,7 \pm 0.71$ \\
\hline 31 & calamenen-10-one-10-nor & 1704 & 1704 & $0,3 \pm 0.01$ & - \\
\hline \multirow[t]{8}{*}{32} & Oplopenone & 1740 & 1740 & $0,1 \pm 0.01$ & - \\
\hline & Extraction time & & & 180 & 90 \\
\hline & Yields & & & $0.025 \pm 0.03$ & $0.023 \pm 0.02$ \\
\hline & Monoterpens hydrocarbons $(\%)$ & & & 0 & 0 \\
\hline & Oxyenated monoterps (\%) & & & 0.1 & 0 \\
\hline & Oxygenated sesquiterpens (\%) & & & 55.4 & 60.6 \\
\hline & Sesquiterpens hydrocarbons (\%) & & & 24.6 & 27.4 \\
\hline & Total volatile compounds (\%) & & & 80.1 & 88 \\
\hline
\end{tabular}

Note: ${ }^{(a)}$ Experimental retention index relative to $\mathrm{C}_{7}-\mathrm{C}_{27} \mathrm{n}$-alkanes on the HP5-MS (apolar capillary column),

(b) literature retention index, ${ }^{(c)}$ Percentage calculated by GC-FID on non-polar HP5-MS capillary column .

(d) Gazim et al,. (2008a), tr: traces $(<0.1 \%)$, - : absence of compound.

characterized by a appreciable amounts of $\alpha$ muurolene representing $41.5 \%$ of total area (Rădulescu et al., 2000) of the plant, the essential oils of Calendula officinalis L. from South Africa were characterized by a greater proportion of $\alpha$-cadinol, $\alpha$-cadinene, $T$ muurolol, epi-bicyclosesquiphellandrene
, limonene, 1.8 cineole and trans- $\beta$-ocimene belonging to class of monoterpens (Okoh et al., 2007). The same author mentioned overwise, the effect of drying on the volatile composition of the oils: fresh flowers oil were dominated by $\alpha$-thujene (26.9\%), T-muurolol $(24.9 \%)$ and 
cadinene $(13.1 \%)$ as the main compounds. On the other hand, died leaves was dominated by 1,8-cinéole (29.4\%), $\alpha$-thujene (17.8\%), $\beta$ pinene $(6.9 \%)$ and $\delta$-cadinene $(9.0 \%)$ while the fresh leaves was found to be rich in T-muurolol (40.9\%), $\alpha$-thujene (19.2\%) and $\delta$-cadinene (11.4\%) (Okoh et al., 2008).

Many volatile constituents identified in this investigation were tested for their anticancer properties. Among of them , $\alpha$ cadinol, showed selective toxicity against human colon adenocarcinoma cells (Sylvestre et al., 2006) (He et al., 1997). Otherwise, it was reported that the essential oils extracted from other medicinal plants containing $\alpha$ pinene, $p$-cymene , $\alpha$-copaene and $\delta$-cadinene as volatile components have a potential antimicrobial and antifungal activities (Bel Hadj Salah-Fatnassi et al., 2017).

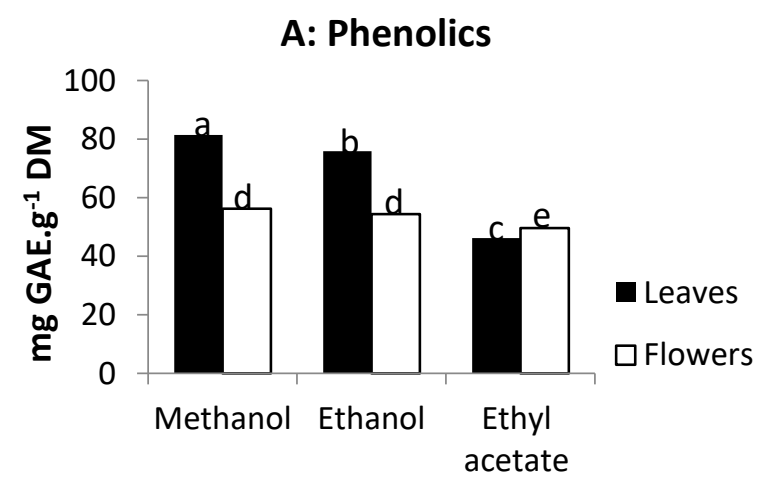

Solvents
3.2. Determination of phenolic content and evaluation of antioxidant and antibiological activities of samples extracts

3.2.1.Effect of solvent on total phenolic content (TPC) and total flavonoid content (TFC)

Three solvent systems were used (methanol, ethanol and ethyl acetate) for phenolic and flavonoid extractions from leaves or flowers of Calendula officinalis L. In the case of leaves, the extract obtained by $100 \%$ methanol showed the highest total phenolic content, TPC (81.4 mg GAE. ${ }^{-1} \mathrm{DM}$ ) and the highest total flavonoids content, TFC (24.11 mg QE.g $\left.{ }^{-1}\right)$. Values obtained with $100 \%$ ethanol were close but statistically different $(p<0.05)$. TPC (46.16 mg GAE.g $\left.{ }^{-1} \mathrm{DM}\right)$ and TFC (19.75 mg QE.g $\left.{ }^{-1}\right)$ obtained by extraction with $100 \%$ ethyl acetate were lower.

In the case of flowers, the same extraction efficiency was recorded for the three solvents for both TPC and TFC but with low yields except for TPC extracted with ethyl acetate(49.6 vs $46.16 \mathrm{mg}$ GAE.g ${ }^{-1} \mathrm{DM}$ for leaves) (Figure2).

Figure 2. Total phenolics (A) and total flavonoids (B) contents of Calendula officinalis L. leaves and flowers according to extraction solvents.

For each graph, different alphabetical letters indicate statistically significant differences between values ( $\mathrm{p}<0.05$, Student's $\mathrm{t}$-test). All values are mean \pm SD. Error bars indicating standard errors $(\mathrm{SD})$ are smaller than the symbol size.

The general results suggest that the values obtained were affected by the type and polarity of extracting solvents. Indeed, this parameter plays a key role in the efficiency of the process because its influence the solubility of the target compounds and the penetrability into the matrix (Rostagno and Prado, 2013). As corroborate by numerous 
authors, in our case, methanol was the best extracting solvent due to its higher polarity and good solubility for phenolic component from plants followed by ethanol and ethyl acetate (Belwal et al., 2016; Roby et al., 2013).

\subsubsection{Evaluation of antioxidant activity of samples extracts}

Various techniques are available to screen the antioxidant activity of vegetal matrices. However, the use of only one method was not efficient to identify all possible mechanisms characterizing an antioxidant. Thus, two complementary in vitro assays namely the DPPH and ABTS free radicals scavenging were selected to evaluate the potential antioxidant activity of methanol, ethanol and ethyl acetate extracts from flowers and leaves of Calendula officinalis L.

The obtained results showed that all the investigated samples extracts exhibits the ability to scavenge the DPPH free radical. Indeed, the $\mathrm{IC}_{50}$ which corresponding of the required concentration of an extract to inhibit the free radical by $50 \%$ present the values ranging between $149.10 \pm 1.36 \mu \mathrm{g} . \mathrm{mL}^{-1}$ and $312.86 \pm 1.40 \mu \mathrm{g} . \mathrm{mL}^{-1}$ (Table 3). The highest DPPH-activity was observed for methanol extract with $\mathrm{IC}_{50}$ values of $149.10 \pm 1.36 \mu \mathrm{g} . \mathrm{mL}$ 1 and $175.21 \pm 1.57 \mu \mathrm{g} . \mathrm{mL}^{-1}$ respectively for leaves and flowers and the lowest one for acetate ethyl extract with $\mathrm{IC}_{50}$ of $285.52 \pm 1.14$ $\mu \mathrm{g} . \mathrm{mL}^{-1}$ and $312.86 \pm 1.40 \mu \mathrm{g} . \mathrm{mL}^{-1}$ respectively for leaves and flowers. Globally, the leaves showed a better antioxidant activity compared with flowers. Regarding the ABTS test, the same results were obtained with the highest $\mathrm{IC}_{50}$ values of $146.29 \pm 1.17 \mu \mathrm{g} \cdot \mathrm{mL}^{-1}$ for leaves methanol extract and $168.44 \pm 1.76 \mu \mathrm{g} \cdot \mathrm{mL}^{-1}$ for flowers methanol extract. Oppositely, the lowest $\mathrm{IC}_{50}$ values were $280.91 \pm 1.1 \mu \mathrm{g} . \mathrm{mL}^{-1}$ and $307.22 \pm 1.06 \mu \mathrm{g} \cdot \mathrm{mL}^{-1}$ for ethyl acetate extracts from leaves and flowers respectively. It should be noted, furthermore, that all the tested extracts exhibits a lowest antioxidant activity compared to the positive control BHT $\left(\mathrm{IC}_{50}=28.12 \pm 0.14 \mu \mathrm{g} . \mathrm{mL}^{-1}\right)$ and Trolox
$\left(\mathrm{IC}_{50}=10.14 \pm 0.11 \mu \mathrm{g} \cdot \mathrm{mL}^{-1}\right) \quad$ respectively for DPPH and ABTS tests.

Table 3. Effect of phenolic compound extracts of Calendula officinalis L. on antioxydant activities.

\begin{tabular}{|l|l|l|}
\hline Samples extracts & IC50 DPPH & IC50 ABTS \\
\hline Leaves extracts & & \\
\hline Methanol & $149.10 \pm 1.36^{\mathrm{a}}$ & $146.29 \pm 1.17^{\mathrm{b}}$ \\
\hline Ethanol & $187.94 \pm 1.23^{\mathrm{c}}$ & $184.83 \pm 1.62^{\mathrm{d}}$ \\
\hline Ethyl acetate & $285.52 \pm 1.14^{\mathrm{e}}$ & $280.91 \pm 1.1^{\mathrm{f}}$ \\
\hline Flowers extracts & & \\
\hline Methanol & $175.21 \pm 1.57^{\mathrm{g}}$ & $168.44 \pm 1.76^{\mathrm{h}}$ \\
\hline Ethanol & $196.48 \pm 1.22^{\mathrm{i}}$ & $192.12 \pm 1.26^{\mathrm{j}}$ \\
\hline Ethyl acetate & $312,86 \pm 1,40^{\mathrm{k}}$ & $307,22 \pm 1,06^{\mathrm{l}}$ \\
\hline Standards & & \\
\hline BHT & $28.12 \pm 0.13$ & -- \\
\hline Trolox & -- & $10.41 \pm 0.11$ \\
\hline
\end{tabular}

-- not applied

Different alphabetical letters indicate statistically significant differences between values ( $\mathrm{p}<0.05$, Student's t-test). All values are mean \pm SD

It should be noted, that the differences noted between the antioxidant activities potential of these crude extracts maybe attributed at the quality and quantity of the phenolics compounds present in the extracts (Mokrani and Madani, 2016; Decker 1997)

\subsubsection{Comparison between DPPH and ABTS methods}

The DPPH and ABTS scavenging assays resulted in close values obtained through the two methods for the same organ and the same solvent but those obtained by DPPH method were slightly highest indicating a lower inhibition capacity compared to ABTS. Our observations are in line with those indicated by some authors which report that ABTS inhibition for samples from vegetables, fruits and beverages is higher than DPPH inhibition (Ghouila et al., 2016; Floegel et al., 2011). This is explained by the fact that the DPPH method is characterized by a lower sensitivity. The reaction of DPPH radicals with most active molecules is slower than ABTS radicals (Binsan et al., 2008; Martysiak-Żurowska and Wenta, 2012) By mixing all data obtained for both organs and the three solvents, it resulted a 
very high correlation $(\mathrm{r}=0.9997)$ between the two methods for determining the antioxidant activity (DPPH and ABTS) (Figure 3). These results suggest that the two methods led to similar antioxidant activity of Calendula officinalis extracts. Vamanu and Nita (2013) have reported the same observation for mushroom extract but with a lower correlation.

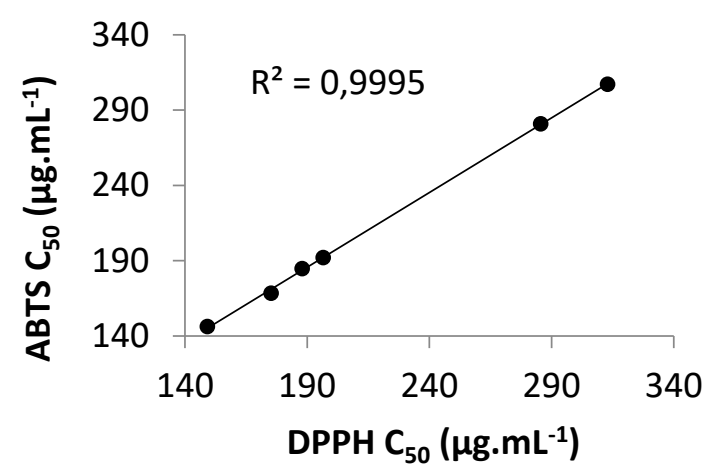

Figure 3. Correlation and regression of DPPH radical scavenging activity versus ABTS radical scavenging activity.

All values are issued from all phenolic compounds extracts (organ and solvent).

\subsubsection{Relation between phenolic contents and antioxidant activity}

A strong relationship between antioxidant capacity (DPPH and ABTS) and total phenolic or flavonoid contents was found (Table 4). This indicates that quantities of antioxidant molecules which were present in the extracts increased linearly with increasing concentrations. These results indicate also that flavonoids were the major contributors to the antioxidant properties of the studied plant. Correlation between phenolic compounds content and antioxidant activity has been reported by several authors and for many species. (Dudonné et al., 2009; Li et al., 2009; Piluzza and Bullitta 2011)
Table 4. Correlation of total phenolic and flavonoid contents with antioxydant activities (DPPH or ABTS).

\begin{tabular}{|l|c|c|c|c|}
\hline & $\begin{array}{c}\text { TPC } \\
\text { Leaves }\end{array}$ & $\begin{array}{c}\text { TPC } \\
\text { Flowers }\end{array}$ & $\begin{array}{c}\text { TFC } \\
\text { Leaves }\end{array}$ & $\begin{array}{c}\text { TFC } \\
\text { Flowers }\end{array}$ \\
\hline DPPH & 0.9912 & 0.9925 & 0.9973 & 0.9471 \\
\hline ABTS & 0.9909 & 0.9522 & 0.9943 & 0.9522 \\
\hline
\end{tabular}

Values represent coefficient correlation (r) calculated according Pearson's method.

\subsubsection{Antibiological activity}

The prepared extracts from flowers and leaves of Calendula officinalis L. were screened against the selected $\mathrm{Gram}^{+}$bacteria, $\mathrm{Gram}^{-}$bacteria and fungi strains using the disc diffusion assay (Table 5). It has been observed that the effectiveness of the samples extracts depends of the tested microorganisms, the type of solvents used and the plant organ. Our finding showed that no antibacterial activity was detected against $\mathrm{Gram}^{-}$bacteria and fungi strains. The resistance of $\mathrm{Gram}^{-}$bacteria to inhibitory effect of the tested extracts could be attributed to lipopolysaccharides in their outer membrane, which make them inherently resistant to external agents, such as hydrophilic dyes, antibiotics and detergents (Hayouni et al., 2007).

Otherwise, the tested extracts were globally most efficient against $\mathrm{Gram}^{+}$bacteria with a diameter of the growth inhibition zone ranging for $8.03 \pm 0.15 \mathrm{~mm}$ to $5.33 \pm 0.41 \mathrm{~mm}$ corresponding at moderate activities.

Methanol flowers extracts were efficient while tested against Bacillus subtilus ATCC6633 and Listeria monocytogenes with a diameter of the growth inhibition zone of $12.37 \pm 0.23 \mathrm{~mm}$ and $8.13 \pm 0.15 \mathrm{~mm}$ respectively. The same observation was done for the leaves extracts with an inhibition zone diameter of $10.9 \pm 0.78 \mathrm{~mm}$ and $12.16 \pm 0.12 \mathrm{~mm}$ against the same bacteria. However, any antibacterial activity was observed against Staphylococcus aureus 693c for both matrices. Ethanol extract from flowers present a moderate antibacterial activity with an inhibition zone diameter of $11.2 \pm 0.26 \mathrm{~mm}$ and $10.8 \pm 0.60 \mathrm{~mm}$ while no activity was observed against Listeria monocytogenes. In the same 
way, tested against the same bacteria, ethanol leaves extracts didn't show any inhibition zone.

Oppositely, a moderate antibacterial activity was recorded against Bacillus subtilus ATCC6633 and Staphylococcus aureus $693 \mathrm{c}$ with an inhibition zone diameter of $10.9 \pm 0.78 \mathrm{~mm}$ and $12.16 \pm 0.12 \mathrm{~mm}$ respectively. Concerning ethyl acetate flowers extract, the antibacterial activity was observed only against Bacillus subtilus ATCC6633 with an inhibition zone diameter of $10.7 \pm 0.35 \mathrm{~mm}$. As for the leaves extracts, an antibacterial activity was recorded against all the tested bacteria with a growth inhibition zone diameter of $8.1 \pm 0.36 \mathrm{~mm}, 10.1 \pm 0.20 \mathrm{~mm}$ and $8.03 \pm 0.15 \mathrm{~mm}$ for Bacillus subtilus ATCC6633, Listeria monocytogenes and Staphylococcus aureus 693 c respectively. It should be noted furthermore, that among all the extracts, leaves methanol extract present the highest growth inhibition zone diameter with $25.33 \pm 0.41 \mathrm{~mm}$ against Bacillus subtilus ATCC6633 corresponding at a great antibacterial activity. The amoxicillin exerted the strongest inhibitory effect against the tested microorganisms compared to all extracts. The $\mathrm{Gram}^{-}$bacteria and the fungi strains were not susceptible to amoxicillin at a concentration of $25 \mu \mathrm{g}$ per disc.

Table 5. Effect of phenolic compound extracts of Calendula officinalis L. on growth inhibition zone diameter sizes $(\mathrm{mm})$.

\begin{tabular}{|c|c|c|c|c|c|c|c|}
\hline & \multicolumn{3}{|c|}{ Leaves extracts $(25 \mu \mathrm{L})$} & \multicolumn{3}{|c|}{ Flowers extracts $(25 \mu \mathrm{L})$} & \multirow[t]{2}{*}{ Amoxicillin } \\
\hline & Methanol & Ethanol & $\begin{array}{c}\text { Ethyl } \\
\text { acetate }\end{array}$ & Methanol & Ethanol & $\begin{array}{c}\text { Ethyl } \\
\text { acetate }\end{array}$ & \\
\hline \multicolumn{8}{|l|}{ Gram $^{+}$} \\
\hline B. subtilis & $25.33 \pm 0.41^{\mathrm{a}}$ & $10.9 \pm 0.78^{\mathrm{b}}$ & $8.1 \pm 0.36^{\mathrm{c}}$ & $12,37 \pm 0.23^{\mathrm{d}}$ & $11.2 \pm 0.26^{\mathrm{e}}$ & $10.7 \pm 0.35^{\mathrm{e}}$ & $45.13 \pm 0.21^{\mathrm{f}}$ \\
\hline L. monocytogenese & $11.16 \pm 0.35^{\mathrm{a}}$ & -- & $10.1 \pm 0.20^{\mathrm{b}}$ & $8.13 \pm 0.15^{c}$ & -- & -- & $28.43 \pm 0.40^{\mathrm{d}}$ \\
\hline S. aureus & -- & $12.16 \pm 0.12^{\mathrm{a}}$ & $8.03 \pm 0.15^{b}$ & -- & $10.8 \pm 0.60^{\mathrm{c}}$ & -- & $34.33 \pm 0.49^{\mathrm{d}}$ \\
\hline \multicolumn{8}{|l|}{ Gram ${ }^{-}$} \\
\hline E. coli & -- & -- & -- & -- & -- & -- & -- \\
\hline P. aeroginosa & -- & -- & -- & -- & -- & -- & -- \\
\hline \multicolumn{8}{|l|}{ Fungi } \\
\hline A. carbonarius & -- & -- & -- & -- & -- & -- & -- \\
\hline U. ramaniana & -- & -- & -- & -- & -- & -- & -- \\
\hline
\end{tabular}

For each line, different alphabetical letters indicate statistically significant differences between values ( $\mathrm{p}<0.05$, Student's t-test). All values are mean \pm SD.

The minimum inhibitory concentration (MIC) was estimated for the extract which showed the interesting antibacterial activity against the $\mathrm{Gram}^{+}$bacteria. A strong antibacterial activity was presented by a low value of MIC (Coulidiati et al., 2009). Globally, perusals of table 6 showed that the IMC values varied from 7.80 to $125 \mu \mathrm{g} . \mathrm{mL}^{-1}$. The lowest minimal inhibitory concentration corresponding to strongest antimicrobial activity was observed for methanol extract from leaves against the standard strain Bacillus subtilus ATCC6633 with IMC of $7.8 \mu \mathrm{g} \cdot \mathrm{mL}^{-1}$. The ethanol extract from flowers and leaves observed a relatively appreciable effectiveness against Staphylococcus aureus 693c with IMC values of $31.25 \mu \mathrm{g} . \mathrm{mL}^{-1}$ and $15.62 \mu \mathrm{g} . \mathrm{mL}^{-1}$ respectively. Also, the leaves methanol extract present a moderate antibacterial activity against Listeria monocytogenes with IMC of $15.62 \mu \mathrm{g} . \mathrm{mL}^{-1}$. For each bacteria strain used, in both vegetal matrice, the lowest antibacterial activity was noted or was not detected for ethyl acetate extract.

This observation could be explained by the quantity of the polyphenols and flavonoids present in the extracts which influence the effectiveness of the extracts against microorganisms (Rodríguez-Vaquero et al., 2013). In fact, the finding literature noted that 
the bioactive compounds such as phenolic compounds, flavonoids, tannins and alkaloids are one of the most important antimicrobial agent present in the plant (Levy, 1994). Some of them act by altering the biochemical systems of microorganisms, binging their protein molecules or causing inflammation of the cells in order to inhibits their life process. (Garrod 1995)

Table 6. Results of minimum inhibitory concentration (MIC) in $\mu \mathrm{g} \cdot \mathrm{mL}^{-1}$ of crude extracts against microorganisms $\left(\mathrm{Gram}^{+}\right.$bacteria)

\begin{tabular}{|l|c|c|c|c|c|c|c|}
\hline Microorganisms & \multicolumn{3}{c|}{ Flowers extracts } & \multicolumn{3}{c|}{ Leaves extracts } & Amox. \\
\cline { 2 - 8 } & Methanol & Ethanol & Ethyl acetate & Methanol & Ethanol & Ethyl acetate \\
\hline B. subtilis & 62.5 & 62.5 & 125 & 7.8 & 62.5 & 125 & 7.8 \\
\hline L. monocytogenese & 125 & -- & -- & 15.62 & -- & 125 & 15.62 \\
\hline S. aureus & -- & 31.25 & -- & -- & 15.62 & 62.5 & 15.62 \\
\hline
\end{tabular}

-- Not detected

\section{Conclusions}

The present study was aimed to investigate, for the first time, the effects of the use of MAHD extraction method on the chemical composition of the essential oils from leaves and flowers of Calendula officinalis L. cultivated in Algeria. This modern and green method allow us to obtain relatively similar extraction yields compared with conventional method (HD) while reducing the extraction time and saving substantial energy. In all extracted oils, the oxygenated sesquiterpens was the dominant family and the $\alpha$-cadinol the main compound, present with different relatives amounts depending on the isolation methods. It showed that the phenolic and flavonoids contents are affected by the solvent type. Thus, in general, methanol was the better extraction solvent for both leaves and flowers of Calendula officinalis. On another hand, the potential antioxidant of methanol, ethanol and ethyl acetate extracts from leaves and flowers was conducted by capturing free DPPH and ABTS radicals in comparison with adequate positive controls BHT and Trolox respectively. Our finding observed the influence of the polarity of solvents on the biological activities of the tested extracts. In fact, methanol extract presented the highest antioxidant activity, for both matrices, while the ethyl acetate extract observed the lowest one. These general observations could be correlated with the total amount of phenolics and flavonoids present in the extract.

The antibacterial activity of the extracts against pathogenic microorganisms was evaluated using the disc diffusion and broth microdilution methods. The comparison was done with a standard antibiotic (Amoxicillin). A moderate to great antibacterial activity was observed against $\mathrm{Gram}^{+}$bacteria. The efficiency of this antibacterial effect depends on extraction solvent and plant organ. Any antifungal and antibacterial activity against $\mathrm{Gram}^{-}$bacteria was detected.

\section{References}

Adams, R.P. (2007). Identification of essential oil components by gas chromatography/mass spectrometry. Journal of the American Society for Mass Spectrometry, 6(8), 671-672.

Amoian, B., Moghadamnia, A.A., Mazandarani, M., Amoian, M.M., Mehrmanesh, S. (2010). The effect of Calendula extract toothpaste on the plaque index and bleeding in gingivitis. Research Journal of Medicinal Plant, 4, 132-140.

Amorati, R., Foti, M.C. \& Valgimigli, L. (2013). Antioxidant activity of essential oils. Journal of Agricultural and Food Chemistry, 61(46), 10835-10847. 
Arora, D., Rani, A., Sharma, A. (2013). A review on phytochemistry and ethnopharmacological aspects of genus Calendula. Pharmacognosy Reviews, 7(14), 179-187.

Bakkali, F., Averbeck, S., Averbeck, D., Zhiri, A., Idaomar, M. (2005). Cytotoxicity and gene induction by some essential oils in the yeast Saccharomyces cerevisiae. Mutation Research/Genetic Toxicology and Environmental Mutagenesis, 585, 1-13.

Bauer, A.W., Kirby, W.M., Sherris, J.C., Turck, M. (1966). Antibiotic susceptibility testing by a standardized single disk method. American Journal of clinical pathology ,45, 493-496.

Bel Hadj Salah-Fatnassi, K., Hassayoun, F., Cheraif, I., Khan, S., Jannet, H.B., Hammami, M., Aouni, M., HarzallahSkhiri, F. (2017). Chemical composition, antibacterial and antifungal activities of flowerhead and root essential oils of Santolina chamaecyparissus L., growing wild in Tunisia. Saudi Journal of Biological Sciences, 24(4), 875-882.

Belwal, T., Dhyani, P., Bhatt, I.D., Rawal, R.S., Pande, V. (2016). Optimization extraction conditions for improving phenolic content and antioxidant activity in Berberis asiatica fruits using response surface methodology (RSM). Food Chemistry, 207, 115-124.

Binsan, W., Benjakul, S., Visessanguan, W., Roytrakul, S., Tanaka, M., Kishimura, H. (2008). Antioxidative activity of Mungoong, an extract paste, from the cephalothorax of white shrimp (Litopenaeus vannamei). Food Chemistry, 106(1), 185-193.

Brand-Williams, W., Cuvelier, M.E., Berset, C. (1995). Use of a free radical method to evaluate antioxidant activity. LWT - Food Science and Technology, 28(1), 25-30.

Ćetković, G.S., Djilas, S.M., ČanadanovićBrunet, J.M., Tumbas, V.T. (2004). Antioxidant properties of marigold extracts. Food Research International, 37(7), 643650.
Chalchat, J.C., Garry, R.P., Michet, A. (1991). Chemical composition of essential oil of Calendula officinalis L. (pot marigold). Flavour and Fragrance Journal, 6(3), 189192.

Chan, C.-H., Yusoff, R., Ngoh, G.-C., Kung, F.W.L. (2011). Microwave-assisted extractions of active ingredients from plants. Journal of Chromatography A, 1218(37), 6213-6225.

Chebouti, M., Merabet, A., Behidj, N., Bissaad, F.Z., Mokadem, A., Akkacha, N. (2014). Antimicrobial activity of phenolic extracts of flowers Calendula officinalis cultivated in Algeria. 14th SGEM Geoconference on Water Resources. Forest, Marine and Ocean Ecosystems. ISBN: 978-619-710514-8/ISSN 1314-2704. June 19-25 vol.2. (pp. 319-324).

Coulidiati, T.H., Millogo-Koné, H., LamienMéda, A., Lamien, C.E., Lompo, M., Kiendrébéogo, M., Bakasso, S., YougbaréZiébrou, M., Millogo-Rasolodimby, J., Nacoulma, O.G. (2009). Antioxidant and antibacterial activities of Combretum nioroense Aubrév. ex Keay (Combretaceae). Pakistan journal of biological sciences : PJBS, 12(3), 264-269.

Crabas, N., Marongiu, B., Piras, A., Pivetta, T., Porcedda, S. (2003). Extraction, Separation and Isolation of Volatiles and Dyes from Calendula officinalis L. and Aloysia triphylla (L'Her.) Britton by Supercritical CO2. Journal of Essential Oil Research, 15(4), 272-277.

Decker, A. (1997). Phenolics: Prooxidants or Antioxidants? Nutrition Reviews, 55(11), 396-398.

Dei Cas, L., Pugni, F., Fico, G. (2015). Tradition of use on medicinal species in Valfurva (Sondrio, Italy). Journal of Ethnopharmacology, 163, 113-134.

Duarte, M.C.T. , Duarte, R.M.T., Rodrigues, R.A.F., Rodrigues, M.V.N. (2017). Characteristics Essential Oils in Food Processing (Chapter 1), 1-19. In S.M.B. Hashemi , A.M. Khaneghah, A. de Souza 
Sant'Ana (Ed.), Essential Oils in Food Processing: Chemistry, Safety and Applications, 1st ed.. (pp. 1-19), New Jersey: Wiley Blackwell, IFT Press.

Dudonné, S., Vitrac, X., Coutiere, P., Woillez, M., Mérillon, J.M. (2009). Comparative study of antioxidant properties and total phenolic content of 30 plant extracts of industrial interest using DPPH, ABTS, FRAP, SOD, and ORAC assays. Journal of Agricultural and Food Chemistry, 57(5), 1768-1774.

Efstratiou, E., Hussain, A.I., Nigam, P.S., Moore, J.E., Ayub, M.A., Rao, J.R. (2012). Antimicrobial activity of Calendula officinalis petal extracts against fungi, as well as Gram-negative and Gram-positive clinical pathogens. Complementary Therapies in Clinical Practice, 18(3), 173176.

Farhat, A., Benmoussa, H., Bachoual, R., Nasfi, Z., Elfalleh, W., Romdhane, M., Bouajila, J. (2017). Efficiency of the optimized microwave assisted extractions on the yield, chemical composition and biological activities of Tunisian Rosmarinus officinalis L. essential oil. Food and Bioproducts Processing, 105, 224-233.

Ferhat, M.A., Meklati, B.Y., Smadja, J., Chemat, F. (2006). An improved microwave Clevenger apparatus for distillation of essential oils from orange peel. Journal of Chromatography A, 1112(1-2), 121-126.

Ferhat, M.A., Tigrine-Kordjani, N., Chemat, S., Meklati, B.Y., Chemat, F. (2007). Rapid Extraction of Volatile Compounds Using a New Simultaneous Microwave Distillation: Solvent Extraction Device. Chromatographia, 65(3-4), 217-222.

Floegel, A., Kim, D.O., Chung, S.J., Koo, S. I., Chun, O.K. (2011). Comparison of ABTS/DPPH assays to measure antioxidant capacity in popular antioxidant-rich US foods. Journal of Food Composition and Analysis, 24(7), 1043-1048.
Garrod, L.P Lambert, H.P, O'Gray, F. (1995). Antibiotics and chemotherapy, $4^{\text {th }}$ Edition (pp199-205), Fourth Ed-Churchill: Livingstones, Edinburgh, London and New york.

Gazim, Z.C., Rezende, C.M., Fraga, S.R., Dias Filho, B.P., Nakamura, C.V., Cortez, D.A.G. (2008a). Analysis of the essential oils from Calendula officinalis growing in Brazil using three different extraction procedures. Revista Brasileira de Ciencias Farmaceuticas/Brazilian Journal of Pharmaceutical Sciences, 44(3), 391-395.

Gazim, Z.C., Rezende, C.M., Fraga, S.R., Svidzinski, T.I.E., Cortez, D.A.G. (2008b). Antifungal activity of the essential oil from Calendula officinalis L. (asteraceae) growing in Brazil. Brazilian Journal of Microbiology, 39(1), 61-63.

Ghouila, Z., Laurent, S., Henoumont, C., Vander Elst, L., Muller, R., Baaliouamer, A. (2016). Rich extract on total polyphenols and antioxidant activity obtained by conventional and nonconventional methods from Ahmeur Bouamer grape seed. Journal of Fundamental and Applied Sciences, 8(3), 692-711.

Hayouni, E.A., Abedrabba, M., Bouix, M., Hamdi, M. (2007). The effects of solvents and extraction method on the phenolic contents and biological activities in vitro of Tunisian Quercus coccifera L. and Juniperus phoenicea L. fruit extracts. Food Chemistry, 105(3), 1126-1134.

He, K., Zeng, L., Shi, G., Zhao, G.X., Kozlowski, J.F., McLaughlin, J.L. (1997). Bioactive Compounds from Taiwania cryptomerioides. Journal of Natural Products, 60(1), 38-40.

J. Mason, T., Chemat, F., Vinatoru, M. (2011). The Extraction of Natural Products using Ultrasound or Microwaves. Current Organic Chemistry, 15(2), 237-247.

Jarić, S., Kostić, O., Mataruga, Z., Pavlović, D., Pavlović, M., Mitrović, M., Pavlović, P. (2018). Traditional wound-healing plants 
used in the Balkan region (Southeast Europe). Journal of Ethnopharmacology, 211, 311-328.

Khalid, K.A., El-Ghorab, A.H. (2006). The Effect of Presowing Low Temperature on Essential Oil Content and Chemical Composition of Calendula officinalis. Journal of Essential Oil Bearing Plants, 9(1), 32-41.

Levy, S. (1994). Drug resistance: the new apocalypse (special issue). Trends Microbiol, 2(10), 341-425.

Li, X., Wu, X., Huang, L. (2009). Correlation between antioxidant activities and phenolic contents of radix Angelicae sinensis (Danggui). Molecules, 14(2), 5349-5361.

Lim, T.K. (2014). Calendula officinalis. In: Edible Medicinal And Non-Medicinal Plants: Volume 7, Flowers. (pp. 213-244). Dordrecht: Springer Netherlands.

Ling, L.T., Yap, S.A., Radhakrishnan, A. K., Subramaniam, T., Cheng, H. M., Palanisamy, U.D. (2009). Standardised Mangifera indica extract is an ideal antioxidant. Food Chemistry, 113(4), 11541159.

Luque de Castro, M.D., Jiménez-Carmona, M.M. \& Fernández-Pérez, V. (1999). Towards more rational techniques for the isolation of valuable essential oils from plants. Trends in Analytical Chemistry, 18(11), 708-716.

Martysiak-Żurowska, D., Wenta, W. (2012). A comparison of ABTS and DPPH methods for assessing the total antioxidant capacity of human milk. Acta Scientiarum Polonorum Technologia Alimentaria, 8389.

Menaceur, F., Benchabane, A., Hazzit, M. \& Baaliouamer, A. (2013). Chemical Composition and Antioxidant Activity of Algerian Juniperus phoenicea L. Extracts. Journal of Biologically Active Products from Nature, 3(1), 87-96.

Mokrani, A., Madani, K. (2016). Effect of solvent, time and temperature on the extraction of phenolic compounds and antioxidant capacity of peach (Prunus persica L.) fruit. Separation and Purification Technology, 162, 68-76.

Muuse, B.G., Cuperus, F. P., Derksen, J.T. (1992). Composition and physical properties of oils from new oilseed crops. Industrial Crops and Products, 1(1), 57-65.

Nicolaus, C., Junghanns, S., Hartmann, A., Murillo, R., Ganzera, M., Merfort, I. (2017). In vitro studies to evaluate the wound healing properties of Calendula officinalis extracts. Journal of Ethnopharmacology, 196, 94-103.

Nikmehr, B., Ghaznavi, H., Rahbar, A., Sadr, S., Mehrzadi, S. (2014). In vitro antileishmanial activity of methanolic extracts of Calendula officinalis flowers, Datura stramonium seeds, and Salvia officinalis leaves. Chinese Journal of Natural Medicines, 12(6), 423-427.

Okoh, O.O., Sadimenko, A.A., Afolayan, A.J. (2007). The effects of age on the yield and composition of the essential oils of Calendula officinalis. Journal of Applied Sciences, 7(23), 3806-3810.

Okoh, O.O., Sadimenko, A.P., Asekun, O.T., Afolayan, A.J. (2008). The effects of drying on the chemical components of essential oils of Calendula officinalis L. African Journal of Biotechnology, 7(10), 1500-1502.

Piluzza, G., Bullitta, S. (2011). Correlations between phenolic content and antioxidant properties in twenty-four plant species of traditional ethnoveterinary use in the Mediterranean area. Pharmaceutical Biology, 49(3), 240-247.

Rădulescu, V., Doneanu, C., Loloiu, T. (2000). CGC investigation of chemical composition of Calendula officinalis. Revue Roumaine de Chimie, 45(3), 271-275.

Roby, M.H.H., Sarhan, M.A., Selim, K.A.H., Khalel, K.I. (2013). Evaluation of antioxidant activity, total phenols and phenolic compounds in thyme (Thymus vulgaris L.), sage (Salvia officinalis L.), and marjoram (Origanum majorana L.) 
extracts. Industrial Crops and Products, 43, 827-831.

Rodríguez-Vaquero, M.J., Aredes AredesFernández, P., Manca de Nadra, M.C. (2013). Phenolic compounds from wine as natural preservatives of fish meat. Food technology and biotechnology, 51(3), 376382.

Rostagno, M.A., Prado, J.M. (2013). Natural Product Extraction: Principles and Applications. Cambridge: Royal Society of Chemistry.

Rotblatt, M. (2000). Herbal medicine: Expanded commission E monographs. Annals of Internal Medicine, 133(6), 487.

Shankar, S.M., Bardvalli, S.G., Jyotirmayee, R., Chethana, Bhushan, K., Kumar, S. (2017). Efficacy of Calendula officinalis extract (marigold flower) as an antimicrobial agent against oral microbes: An invitro study in comparison with chlorhexidine digluconate. Journal of Clinical and Diagnostic Research, 11(10), ZC05-ZC10.

Singleton, V.L., Orthofer, R., LamuelaRaventós, R.M. (1999). Analysis of total phenols and other oxidation substrates and antioxidants by means of Folin-Ciocalteu reagent. In: Methods in Enzymology. (Pp. 152-178). Academic Press.

Sylvestre, M., Pichette, A., Longtin, A., Nagau, F., Legault, J. (2006). Essential oil analysis and anticancer activity of leaf essential oil of Croton flavens L. from Guadeloupe. Journal of Ethnopharmacology, 103(1), 99102.

Thach, L.N., Nhung, T.H., My, V.T.N., Tran, H.A. (2013). The new rich source of rotundifolone: Mentha aquatica Linn. var. crispa oil from microwave-assisted hydrodistillation. Journal of Essential Oil Research, 25(1), 39-43.

Ukiya, M., Akihisa, T., Yasukawa, K., Tokuda, H., Suzuki, T., Kimura, Y. (2006). AntiInflammatory, Anti-Tumor-Promoting, and Cytotoxic Activities of Constituents of Marigold (Calendula officinalis) Flowers. Journal of Natural Products, 69 (12), 16921696.

Vamanu, E., Nita, S. (2013). Antioxidant capacity and the correlation with major phenolic compounds, anthocyanin, and tocopherol content in various extracts from the wild edible Boletus edulis mushroom. BioMed Research International, 12, Article ID 313905.

Wikler, M.A. (2009). Methods for Dilution Antimicrobial Susceptibility Test for Bacteria that Grow Aerobically. Eighth ed., Approved Standard M7-A8, National Committee for Clinical Laboratory Standards, Wayne, PA, US, 29 (2).

Yoshikawa, M., Murakami, T., Kishi, A., Kageura, T., Matsuda, H. (2001). Medicinal Flowers. III. Marigold.(1): Hypoglycemic, Gastric Emptying Inhibitory, and Gastroprotective Principles and New Oleanane-Type Triterpene Oligoglycosides, Calendasaponins A, B, C, and D, from Egyptian Calendula officinalis. Chemical and Pharmaceutical Bulletin, 49(7), 863870.

\section{Acknowledgements}

The authors gratefully acknowledge Pr. Nabila Amirouche from the Laboratory of Biology and Physiology of Organisms (LBPO), Faculty of Biological Sciences, (USTHB), Algiers, Algeria, for the botanical identification. 